Original Article

\title{
Faktor-faktor Kepuasan Pasien Rawat Inap Di RSU Gladish Medical Center Pesawaran
}

\section{Factors of Inpatient Satisfaction at RSU Gladish Medical Center Pesawaran General Hospital}

\author{
Gladis Pretirose ${ }^{1 *}$, Bambang Setiaji², M. Djakfar Sadik ${ }^{2}$ \\ ${ }^{1}$ Program Pascasarjana Magister Kesehatan Masyarakat, Fakultas Kesehatan Universitas \\ Mitra Indonesia \\ ${ }^{2}$ Prodi Kesehatan Masyarakat, Fakultas Kesehatan Universitas Mitra Indonesia
}

\author{
(*gladispretirose@gmail.com)
}

\begin{abstract}
ABSTRAK
Penelitian ini bertujuan untuk mengetahui faktor-faktor yang berhubungan dengan kepuasan pasien di Instalasi Rawat Inap RSU Gladish Medical Center Pesawaran. Jenis penelitian ini adalah penelitian kuantitatif dengan pendekatan cross sectional. Populasi penelitian ini adalah 200 pasien di Ruang Rawat Inap dari bulan April sampai Mei 2021 dengan melibatkan 133 responden yang ditentukan dengan rumus Slovin. Analisis yang digunakan adalah analisis univariat, bivariat (chi-square) multivariat (regresi logistik berganda). Studi ini menemukan hubungan antara jenis kelamin ( $p$-value= 0,017; OR:2,41), usia ( $p$-value $=0,000$; OR: 7,45), pendidikan ( $p$-value $=0,000 ;$ OR: 31,28), pekerjaan ( $p$-value $=0,007 ;$ OR:2,75), penggunaan asuransi $(p$-value $=0,014 ;$ OR:2,45), Tangible $(p$-value $=0,008 ;$ OR:2,62), Realibilitas ( $p$-value $=0,004$; OR:2,83), Responsiveness ( $p$-value $=0,021 ;$ OR: 2,33), Asurance ( $p$-value $=0,009$; OR: 1,63), dan Empati ( $p$-value=0,019; OR: 2,48). Disimpulkan bahwa faktor yang paling dominan berhubungan dengan kepuasan pasien rawat inap di Gladish Medical Center RSU Pesawaran adalah pendidikan.
\end{abstract}

Kata kunci : Jenis Kelamin, Usia, Pendidikan, Pekerjaan, Penggunaan Asuransi, Kualitas Pelayanan, Kepuasan

\section{ABSTRACT}

This study aimed o determine the factors related to patient satisfaction at the Inpatient Installation of RSU Gladish Medical Center Pesawaran. This type of research was quantitative research with a cross-sectional approach. The population of this study was 200 patients in the Inpatient Room from April to May 2021, involving 133 respondents determined by the Slovin formula. The analysis used univariate analysis, bivariate (chi-square) multivariate (multiple logistic regression). The study found a relationship between gender ( $p$-value $=0.017 ;$ OR:2.41), age ( $p$-value $=0.000 ;$ OR:7.45), education ( $p$ value $=0.000 ;$ OR:31.28), occupation ( $p$-value $=0.007 ;$ OR:2.75), insurance usage ( $p$-value=0.014; OR:2.45), Tangible ( $p$-value=0.008; OR:2.62), Realibility ( $p$-value $=0.004 ;$ OR:2.83), Responsiveness ( $p$-value =0.021; OR:2,33), Assurance ( $p$-value=0.009; OR:1.63), Empathy ( $p$-value=0.019; OR:2.48). It is concluded that the most dominant factor related to inpatients' satisfaction at the Gladish Medical Center Pesawaran General Hospital is education.

Keywords : Gender, Age, Education, Occupation, Use Of Insurance, Service Quality, Satisfaction https://doi.org/10.33860/jik.v15i2.495 


\section{PENDAHULUAN}

Keberadaan pelayanan kesehatan merupakan hal penting untuk meningkatkan derajat kesehatan masyarakat ${ }^{1,2}$. Berbagai pelayanan kesehatan primer maupun tersier baik pemerintah atau swasta dapat membantu masyarakat dalam mengakses pelayanan kesahatan di daerah daerah. Pelayanan kesehatan disuatu daerah memberikan kesempatan masyarakat untuk memilih fasilitas kesehatan yang diinginkan dan sesuai dengan kebutuhan masyarakat ${ }^{3-5}$.

Rumah Sakit mempunyai kewajiban memberi pelayanan kesehatan yang aman, bermutu, anti-diskriminasi, dan efektif dengan mengutamakan kepentingan pasien sesuai dengan standar pelayanan Rumah $\mathrm{Sakit}^{6-8}$. Sebagai acuan dalam melayani pasien Rumah Sakit wajib membuat, melaksanakan, dan menjaga standar mutu pelayanan kesehatan. Dalam upaya peningkatan mutu pelayanan tersebut Rumah Sakit wajib dilakukan akreditasi secara berkala minimal 3 (tiga) tahun sekali. Akreditasi ini bertujuan untuk meningkatkan mutu pelayanan RS, meningkatkan keselamatan pasien RS, meningkatkan perlindungan bagi pasien, masyarakat, SDM RS dan RS sebagai institusi, dan mendukung program Pemerintah dibidang Kesehatan?.

Pasien yang memiliki rasa puas terhadap rumah sakit dapat diartikan bahwa rumah sakit tersebut memiliki pelayanan kesehatan yang bermutu. Kepuasan adalah suatu tingkat perasaan yang timbul sebagai akibat dari kinerja layanan kesehatan yang diperolehnya setelah pasien membandingkannya dengan yang diharapkan. Kepuasan pasien menjadi bagian integral dan menyeluruh dari kegiatan jaminan mutu pelayanan kesehatan ${ }^{10,11}$. Rasa puas yang dimiliki seorang pasien dapat membuat persepsi pasien terhadap pelayanan yang diberikan oleh rumah sakit, maka ketika seorang pasien tersebut mengalami sakit akan kembali lagi ke rumah sakit untuk mendapatkan pelayanan yang bermutu.

Berdasarkan data komplain RSU Gladish Medical Center Pesawaran yang masuk kedalam kotak saran pada tahun 2019 terdapat 20 komplain sedangkan pada tahun 2020 terdapat 50 komplain. Terdapat kenaikan komplainan pada tahun 2020 sebanyak 30 komplain. Komplain yang diterima berdasarkan kotak saran yaitu perawat yang lama dalam memberikan pelayanan, fasilitas ruang poliklinik yang kurang baik, fasilitas kamar rawat inap yang panas, dokter yang tidak melakukan visit kepada pasien, fasilitas mushola yang kurang memadai, informasi yang diberikan perawat kurang jelas dan petugas rumah sakit yang kurang ramah. Adapun perbaikan-perbaikan yang dilakukan oleh RSU Gladish Medical Center, dilakukan secara berkesinambungan, namun pada tahun 2020 belum dapat dilaksanakan secara maksimal dikarenakan pembiayaan banyak digunakan untuk membeli alat perlindungan diri (APD), yang harganya meningkat dan langka dipasaran.

Tujuan penelitian adalah untuk mengetahui mengetahui faktor- faktor yang berhubungan dengan kepuasan pasien di Instalasi Rawat Inap RSU Gladish Medical Center.

\section{METODE PENELITIAN}

Jenis penelitian adalah kuantitatif desain analitik dengan pendekatan cross sectional. Penelitian ini telah dilakukan pada bulan AprilMei 2021. Populasi penelitian ini Pasien di RSU Gladish Medical Center Pesawaran rata-rata pasien rawat inap perbulan sebanyak 200 orang. Sampel sebanyak 133 responden ditentukan dengan rumus Slovin. Pengumpulan data ini, dilakukan dari sumber data primer (kuesioner) untuk seluruh variable.

Pengolahan data dalam penelitian ini ada 4 yaitu Editing Data, Coding, Processing, Cleaning dan analisis data mengguna kan program komputer yang dilakukan 2 tahap yaitu analisis univariat dan bivariat menggunakan uji Chi Square serta analisis multivariat menggunakan regresi logistik berganda.

\section{HASIL}

Tabel 1. Distribusi karakteristik responden

\begin{tabular}{llll}
\hline \multicolumn{1}{c}{ Variabel } & \multicolumn{1}{c}{ Kategori } & $\mathrm{n}$ & $\%$ \\
\hline Kepuasan & Puas & 90 & 60,8 \\
\cline { 2 - 4 } Pasien & Tidak Puas & 58 & 39,2 \\
\hline Jenis & Laki-Laki & 88 & 59,5 \\
\cline { 2 - 4 } Kelamin & Perempuan & 60 & 40,5 \\
\hline \multirow{2}{*}{ Umur } & Produktif & 85 & 57,4 \\
\cline { 2 - 4 } & Tidak & 63 & 42,6 \\
& Produktif & & \\
\hline \multirow{2}{*}{ Pendidikan } & Sekolah & 80 & 54,1 \\
\cline { 2 - 4 } & Tidak Sekolah & 68 & 45,9 \\
\hline Pekerjaan & Bekerja & 95 & 64,2 \\
\cline { 2 - 4 } & Tidak Bekerja & 53 & 35,8 \\
\hline
\end{tabular}




\begin{tabular}{llcc}
\hline Penggunaan & Menggunakan & 98 & 66,2 \\
\cline { 2 - 4 } Asuransi & Tidak & 50 & 33,8 \\
& Menggunakan & & \\
\hline \multirow{2}{*}{ Tangible } & Baik & 80 & 54,1 \\
\cline { 2 - 4 } Realibility & Buruk & 68 & 45,9 \\
& Baik & 84 & 56,8 \\
& Buruk & 64 & 43,2 \\
\hline \multirow{2}{*}{ Responsivene } & Baik & 80 & 54,1 \\
\cline { 2 - 4 } Assurance & Buruk & 68 & 45,9 \\
\hline Empathy & Baik & 92 & 62,2 \\
\cline { 2 - 4 } & Buruk & 56 & 37,8 \\
\cline { 2 - 4 } & Baik & 102 & 68,9 \\
\hline & Buruk & 46 & 31,1 \\
\hline
\end{tabular}

Berdasarkan tabel 1 menunjukkan bahwa proporsi responden yang yang puas dengan pelayanan rawat inap di RSU Gladish Medical Center Pesawaran. sebanyak 60,8\% dan yang tidak puas berjumlah $39,2 \%$. Diketahui sebagian besar jenis kelamin laki-laki yaitu sebanyak 59,5\%. Proporsi Umur responden tentang pelayanan rawat inap di RSU Gladish Medical Centerproduktif 57,4\%, responden, dengan pendidikan sekolah lebih mendominasi yaitu sebanyak $54,1 \%$. Responden yang bekerja lebih mendominasi yaitu sebanyak 64,2\%. Proporsi penggunaan Asuransi diketahui menggunakan lebih mendominasi yaitu sebanyak $66,2 \%$. Responden yang menyatakan tangible dalam kategori baik sebanyak $54,1 \%$, sementara responden yang menyatakan tangible buruk berjumlah $45,9 \%$. Responden yang menyatakan reability dalam kategori baik sebanyak $56,8 \%$, sementara responden yang menyatakan tangible buruk berjumlah 43,2\%. Responden yang menyatakan reponsivenes dalam kategori baik sebanyak 54,1\%, sementara responden yang menyatakan responsivnes buruk berjumlah $45,9 \%$. Responden yang menyatakan Assurance dalam kategori baik sebanyak $62,2,1 \%$, sementara responden yang menyatakan assurance buruk berjumlah 37,8\%. Responden yang menyatakan emphaty dalam kategori baik sebanyak $68,8 \%$, sementara responden yang menyatakan Emphaty buruk berjumlah $31,1 \%$.

Tabel 2. Hubungan variabel dan kepuasan responden

\begin{tabular}{|c|c|c|c|c|c|c|c|c|}
\hline \multirow{3}{*}{ Variabel } & \multicolumn{4}{|c|}{ Kepuasan } & \multirow{2}{*}{\multicolumn{2}{|c|}{ Total }} & \multirow{3}{*}{$p$ value } & \multirow{3}{*}{$O R$} \\
\hline & \multicolumn{2}{|c|}{ Puas } & \multicolumn{2}{|c|}{ Tidak Puas } & & & & \\
\hline & $\mathrm{n}$ & $\%$ & $\mathrm{n}$ & $\%$ & $\mathrm{~N}$ & $\%$ & & \\
\hline $\begin{array}{l}\text { Jenis Kelamin } \\
\text { Laki-Laki } \\
\text { Perempuan }\end{array}$ & $\begin{array}{l}61 \\
29\end{array}$ & $\begin{array}{l}69,3 \\
48,3\end{array}$ & $\begin{array}{l}27 \\
31\end{array}$ & $\begin{array}{l}30,7 \\
51,7\end{array}$ & $\begin{array}{l}88 \\
60\end{array}$ & $\begin{array}{l}100 \\
100\end{array}$ & 0,017 & $\begin{array}{c}2.415 \\
(1.24-4.76)\end{array}$ \\
\hline $\begin{array}{l}\text { Umur } \\
\text { Produktif } \\
\text { Tidak Produktif }\end{array}$ & $\begin{array}{l}68 \\
22\end{array}$ & $\begin{array}{l}80,0 \\
34,9\end{array}$ & $\begin{array}{l}17 \\
41\end{array}$ & $\begin{array}{c}2,0 \\
65,1\end{array}$ & $\begin{array}{l}85 \\
63\end{array}$ & $\begin{array}{l}100 \\
100\end{array}$ & 0,000 & $\begin{array}{c}7.45 \\
(3.54- \\
15.65) \\
\end{array}$ \\
\hline $\begin{array}{l}\text { Pendidikan } \\
\text { Tinggi } \\
\text { Rendah }\end{array}$ & $\begin{array}{l}73 \\
17\end{array}$ & $\begin{array}{l}91,3 \\
25,0\end{array}$ & $\begin{array}{c}7 \\
51\end{array}$ & $\begin{array}{c}8,8 \\
75,0\end{array}$ & $\begin{array}{l}80 \\
68\end{array}$ & $\begin{array}{l}100 \\
100\end{array}$ & 0,000 & $\begin{array}{c}31.28 \\
(12.09- \\
30.90)\end{array}$ \\
\hline $\begin{array}{l}\text { Pekerjaan } \\
\text { Tinggi } \\
\text { Rendah } \\
\end{array}$ & $\begin{array}{l}66 \\
24 \\
\end{array}$ & $\begin{array}{l}69,5 \\
45,3 \\
\end{array}$ & $\begin{array}{l}29 \\
29\end{array}$ & $\begin{array}{l}30,5 \\
54,7\end{array}$ & $\begin{array}{l}95 \\
53\end{array}$ & $\begin{array}{l}100 \\
100\end{array}$ & 0,007 & $\begin{array}{c}2.75 \\
(1.37-5.51)\end{array}$ \\
\hline $\begin{array}{l}\text { Penggunaan Asuransi } \\
\text { Menggunakan } \\
\text { Tidak menggunakan }\end{array}$ & $\begin{array}{l}67 \\
23 \\
\end{array}$ & $\begin{array}{l}68,4 \\
46,0\end{array}$ & $\begin{array}{l}31 \\
27\end{array}$ & $\begin{array}{l}31,6 \\
54,0\end{array}$ & $\begin{array}{l}98 \\
50\end{array}$ & $\begin{array}{l}100 \\
100 \\
\end{array}$ & 0,014 & $\begin{array}{c}2.48 \\
(1.25-5.11)\end{array}$ \\
\hline $\begin{array}{l}\text { Tangible } \\
\text { Baik } \\
\text { Buruk }\end{array}$ & $\begin{array}{l}57 \\
33\end{array}$ & $\begin{array}{l}71,3 \\
48,5\end{array}$ & $\begin{array}{l}23 \\
35\end{array}$ & $\begin{array}{l}28,7 \\
51,5\end{array}$ & $\begin{array}{l}80 \\
68\end{array}$ & $\begin{array}{l}100 \\
100\end{array}$ & 0,008 & $\begin{array}{c}2.62 \\
(1.33-5.18)\end{array}$ \\
\hline $\begin{array}{l}\text { Realibility } \\
\text { Baik } \\
\text { Buruk }\end{array}$ & $\begin{array}{l}60 \\
30\end{array}$ & $\begin{array}{l}71,4 \\
46,9\end{array}$ & $\begin{array}{l}24 \\
34\end{array}$ & $\begin{array}{l}28,6 \\
53,1\end{array}$ & $\begin{array}{l}84 \\
64\end{array}$ & $\begin{array}{l}100 \\
100\end{array}$ & 0,004 & $\begin{array}{c}2.83 \\
(1.43-5.60\end{array}$ \\
\hline $\begin{array}{l}\text { Responsivenes } \\
\text { Baik } \\
\text { Buruk }\end{array}$ & $\begin{array}{l}56 \\
34 \\
\end{array}$ & $\begin{array}{l}70,0 \\
50,0\end{array}$ & $\begin{array}{l}24 \\
34 \\
\end{array}$ & $\begin{array}{l}30,0 \\
50,0\end{array}$ & $\begin{array}{l}80 \\
68 \\
\end{array}$ & $\begin{array}{l}100 \\
100 \\
\end{array}$ & 0,021 & $\begin{array}{c}2.33 \\
(1.18-4.57)\end{array}$ \\
\hline $\begin{array}{l}\text { Assurance } \\
\text { Baik } \\
\text { Buruk }\end{array}$ & $\begin{array}{l}64 \\
26 \\
\end{array}$ & $\begin{array}{l}69,6 \\
46,4 \\
\end{array}$ & $\begin{array}{l}28 \\
30 \\
\end{array}$ & $\begin{array}{l}30,4 \\
53,6\end{array}$ & $\begin{array}{l}92 \\
56\end{array}$ & $\begin{array}{l}100 \\
100 \\
\end{array}$ & 0,009 & $\begin{array}{c}1.63 \\
(1.32-5.24)\end{array}$ \\
\hline $\begin{array}{l}\text { Empathy } \\
\text { Baik } \\
\text { Buruk }\end{array}$ & $\begin{array}{l}69 \\
21\end{array}$ & $\begin{array}{l}67,6 \\
45,7\end{array}$ & $\begin{array}{l}33 \\
25\end{array}$ & $\begin{array}{l}32,4 \\
54,3\end{array}$ & $\begin{array}{c}102 \\
46\end{array}$ & $\begin{array}{l}100 \\
100\end{array}$ & 0,019 & $\begin{array}{c}2.48 \\
(1.22-5.07)\end{array}$ \\
\hline
\end{tabular}


Hubungan antar variabel terhadap kepuasan responden disajikan pada Tabel 2. Hasil analisis Jenis Kelamin dengan kepuasan pasien rawat inap di RSU Gladish Medical Center Pesawaran diperoleh bahwa dari 88 responden yang berjenis kelamin Laki-laki ada sebanyak $61(69,3 \%)$ yang puas terhadap pelayanan rawat inap rawat di RSU Gladish Medical Center Pesawaran. Sedangkan dari 60 responden perempuan terdapat $31(51,7 \%)$ yang tidak puas terhadap pelayanan rawat inap rawat di RSU Gladish Medical Center Pesawaran. Hasil analisis chi square diperoleh $p v=0,017$ maka ada hubungan antara Jenis Kelamin dengan kepuasan pasien rawat inap di RSU Gladish Medical Center Pesawaran. Nilai OR sebesar 2,41 menunjukkan bahwa responden laki-laki berpeluang 2 kali merasa puas dengan pelayanan rawat inap di RSU Gladish Medical Center Pesawaran dibandingkan responden perempuan.

Hasil analisis hubungan umur dengan kepuasan pasien rawat inap di RSU Gladish Medical Center Pesawaran diperoleh bahwa dari 85 responden yang berumur produktif ada sebanyak $68(80,0 \%)$ yang puas terhadap pelayanan rawat inap rawat di RSU Gladish Medical Center Pesawaran. Sedangkan dari 63 responden yang berumur tidak produktif terdapat $41(65,1 \%)$ yang tidak puas terhadap pelayanan rawat inap rawat di RSU Gladish Medical Center Pesawaran. Hasil analisis chi square diperoleh $p v=0,000$ maka ada hubungan antara umur dengan kepuasan pasien rawat inap di RSU Gladish Medical Center Pesawaran. Nilai OR sebesar 7,45 menunjukkan bahwa responden umur produktif 7 kali merasa puas dengan pelayanan rawat inap di RSU Gladish Medical Center Pesawaran dibandingkan responden berumur tidak produktif.

Hasil analisis hubungan pendidikan dengan kepuasan pasien rawat inap di RSU Gladish Medical Center Pesawaran diperoleh bahwa dari 80 responden yang sekolah ada sebanyak $73(91,3 \%)$ yang puas terhadap pelayanan rawat inap rawat di RSU Gladish Medical Center Pesawaran. Sedangkan dari 68 responden yang tidak sekolah terdapat 51 $(26,6 \%)$ yang tidak puas terhadap pelayanan rawat inap rawat di RSU Gladish Medical Center Pesawaran. Hasil analisis chi square diperoleh $p v=0,000$ maka ada hubungan antara pendidikan dengan kepuasan pasien rawat inap di RSU Gladish Medical Center Pesawaran. Nilai OR sebesar 31,28 menunjukkan bahwa responden yang sekolah 31 kali merasa puas dengan pelayanan rawat inap di RSU Gladish Medical Center Pesawaran dibandingkan responden tidak sekolah.

Hasil analisis hubungan pekerjaan dengan kepuasan pasien rawat inap di RSU Gladish Medical Center Pesawaran diperoleh bahwa dari 95 responden yang bekerja ada sebanyak $66(69,5 \%)$ yang puas terhadap pelayanan rawat inap rawat di RSU Gladish Medical Center Pesawaran. Sedangkan dari 53 responden yang tidak bekerja terdapat $29(54,7 \%)$ yang tidak puas terhadap pelayanan rawat inap rawat di RSU Gladish Medical Center Pesawaran. Hasil analisis chi square diperoleh $p v=0,007$ maka ada hubungan antara pekerjaan dengan kepuasan pasien rawat inap di RSU Gladish Medical Center Pesawaran. Nilai OR sebesar 2,75 menunjukkan bahwa responden yang bekerja 2 kali merasa puas dengan pelayanan rawat inap di RSU Gladish Medical Center Pesawaran dibandingkan responden tidak bekerja

Hasil analisis hubungan penggunaan asuransi dengan kepuasan pasien rawat inap di RSU Gladish Medical Center Pesawaran diperoleh bahwa dari 98 responden yang menggunakan asuransi ada sebanyak 67 $(68,4 \%)$ yang puas terhadap pelayanan rawat inap rawat di RSU Gladish Medical Center Pesawaran. Sedangkan dari 50 responden yang tidak menggunakan Asuransi terdapat 27 $(54,0 \%)$ yang tidak puas terhadap pelayanan rawat inap rawat di RSU Gladish Medical Center Pesawaran. Hasil analisis chi square diperoleh $p v=0,014$ maka ada hubungan antara penggunaan asuransi dengan kepuasan pasien rawat inap di RSU Gladish Medical Center Pesawaran. Nilai OR sebesar 2,53 menunjukkan bahwa responden yang menggunakan asuransi 2 kali merasa puas dengan pelayanan rawat inap di RSU Gladish Medical Center Pesawaran dibandingkan responden tidak menggunakan asuransi

Hasil analisis hubungan tangible dengan kepuasan pasien rawat inap di RSU Gladish Medical Center Pesawaran diperoleh bahwa dari 80 responden yang menyatakan tangible baik ada sebanyak $57(71,3 \%)$ yang puas terhadap pelayanan rawat inap rawat di RSU Gladish Medical Center Pesawaran. Sedangkan dari 68 responden yang menyatakan tangible buruk terdapat $35(51,5 \%)$ yang tidak puas terhadap pelayanan rawat inap rawat di RSU Gladish Medical Center Pesawaran. Hasil 
analisis chi square diperoleh $p v=0,008$ maka ada hubungan antara tangible dengan kepuasan pasien rawat inap di RSU Gladish Medical Center Pesawaran. Nilai OR sebesar 1,62 menunjukkan bahwa responden yang menyatakan tangible baik 1 kali merasa puas dengan pelayanan rawat inap di RSU Gladish Medical Center Pesawaran dibandingkan responden menyatakan tangible buruk.

Hasil analisis hubungan Realibility dengan kepuasan pasien rawat inap di RSU Gladish Medical Center Pesawaran diperoleh bahwa dari 84 responden yang menyatakan Realibility baik ada sebanyak $60(71,4 \%)$ yang puas terhadap pelayanan rawat inap rawat di RSU Gladish Medical Center Pesawaran. Sedangkan dari 64 responden yang menyatakan Realibility buruk terdapat $34 \quad(53,1 \%)$ yang tidak puas terhadap pelayanan rawat inap rawat di RSU Gladish Medical Center Pesawaran. Hasil analisis chi square diperoleh $p v=0,008$ maka ada hubungan antara Realibility dengan kepuasan pasien rawat inap di RSU Gladish Medical Center Pesawaran. Nilai OR sebesar 2,83 menunjukkan bahwa responden yang menyatakan Realibility baik1 kali merasa puas dengan pelayanan rawat inap di RSU Gladish Medical Center Pesawaran dibandingkan responden menyatakan Realibility buruk.

Hasil analisis hubungan Responsivenes dengan kepuasan pasien rawat inap di RSU Gladish Medical Center Pesawaran diperoleh bahwa dari 80 responden yang menyatakan Responsivenes baik ada sebanyak $56(70,0 \%)$ yang puas terhadap pelayanan rawat inap rawat di RSU Gladish Medical Center Pesawaran. Sedangkan dari 68 responden yang menyatakan Responsivenes buruk terdapat $34(50,0 \%)$ yang tidak puas terhadap pelayanan rawat inap rawat di RSU Gladish Medical Center Pesawaran. Hasil analisis chi square diperoleh $p v=0,021$ maka ada hubungan antara Responsivenes dengan kepuasan pasien rawat inap di RSU Gladish Medical Center Pesawaran. Nilai OR sebesar 2,33 menunjukkan bahwa responden yang menyatakan Responsivenes baik 2 kali

Tabel 3. Hubungan umur, pendidikan, responsiveness, dan empathy terhadap kepuasan responden

\begin{tabular}{lrrrr}
\hline \multicolumn{1}{c}{ Variabel } & \multicolumn{1}{c}{ EXP (B) } & \multicolumn{2}{c}{$95 \%$ CI } \\
\hline Umur & 0,002 & 6,320 & 2,022 & 19,755 \\
\hline Pendidikan & 0,000 & 22,324 & 6,913 & 72,096 \\
\hline Responsivenes & 0,029 & 3,497 & 1,139 & 10,738 \\
\hline Empathy & 0,018 & 4,172 & 1,278 & 13,621 \\
\hline Constant & 0,000 &, 000 & & \\
\hline
\end{tabular}

Hasil analisis multivariat ini terdapat 4 merasa puas dengan pelayanan rawat inap di RSU Gladish Medical Center Pesawaran dibandingkan responden menyatakan Responsivenes buruk.

Hasil analisis hubungan Assurance dengan kepuasan pasien rawat inap di RSU Gladish Medical Center Pesawaran diperoleh bahwa dari 92 responden yang menyatakan Assurance baik ada sebanyak $64(69,6 \%)$ yang puas terhadap pelayanan rawat inap rawat di RSU Gladish Medical Center Pesawaran. Sedangkan dari 56 responden yang menyatakan Assurance buruk terdapat $30 \quad(53,6 \%)$ yang tidak puas terhadap pelayanan rawat inap rawat di RSU Gladish Medical Center Pesawaran. Hasil analisis chi square diperoleh $p v=0,009$ maka ada hubungan antara Assurance dengan kepuasan pasien rawat inap di RSU Gladish Medical Center Pesawaran. Nilai OR sebesar 1,63 menunjukkan bahwa responden yang menyatakan Assurance baik 1 kali merasa puas dengan pelayanan rawat inap di RSU Gladish Medical Center Pesawaran dibandingkan responden menyatakan Assurance buruk.

Hasil analisis hubungan Empathy dengan kepuasan pasien rawat inap di RSU Gladish Medical Center Pesawaran diperoleh bahwa dari 102 responden yang menyatakan Empathy baik ada sebanyak $69(67,6 \%)$ yang puas terhadap pelayanan rawat inap rawat di RSU Gladish Medical Center Pesawaran. Sedangkan dari 46 responden yang menyatakan Empathy buruk terdapat $25(54,3 \%)$ yang tidak puas terhadap pelayanan rawat inap rawat di RSU Gladish Medical Center Pesawaran. Hasil analisis chi square diperoleh $p v=0,019$ maka ada hubungan antara Empathy dengan kepuasan pasien rawat inap di RSU Gladish Medical Center Pesawaran. Nilai OR sebesar 2,48 menunjukkan bahwa responden yang menyatakan Empathy baik 2 kali merasa puas dengan pelayanan rawat inap di RSU Gladish Medical Center Pesawaran dibandingkan responden menyatakan Empathy buruk. 
pasien rawat inap di RSU Gladish Medical Center Pesawaran yaitu umur, pendidikan, responsivenes dan empathy (Tabel 3.). Hasil ini juga menjelaskan bahwa faktor yang paling dominan berhubungan dengan kepuasan pasien rawat inap di RSU Gladish Medical Center Pesawaran adalah variable pendidikan $(p=0,000$ dan $\mathrm{OR}=22,3$ ).

\section{PEMBAHASAN}

\section{Hubungan Jenis Kelamin dengan Kepuasan Pasien}

Analisis bivariat menunjukkan adanya hubungan antara Jenis Kelamin dengan kepuasan pasien rawat inap di RSU Gladish Medical Center Pesawaran p $(0,017)<0,05$. Perbedaan jenis kelamin berpengaruh terhadap penggunaan pelayanan kesehatan, perbedaan ini baik secara biologis (sex) maupun secara sosial (gender). Secara biologis, perempuan memiliki kondisi reproduksi yang lebih kompleks dibanding dengan laki-laki, dan secara sosial karena posisinya, perempuan lebih rentan terhadap berbagai macam penyakit dibanding dengan laki-laki termasuk dalam menjalani kehamilan. Pola relasi gender yang ada di masyarakat sangat mempengaruhi polapola hidup masyarakat, termasuk didalamnya pola pengambilan keputusan.

Menurut Woro dan Naili (2013), bahwa tujuan dari suatu bisnis adalah untuk menciptakan para pelanggan yang merasa puas $^{12}$. Terciptanya kepuasan pelanggan dapat memberikan beberapa manfaat, di antaranya hubungan antara perusahaan dan pelanggannya menajdi harmonis, memberikan dasar yang baik bagi pembelian ulang dan terciptanya loyalitas pelanggan dan membentuk suatu rekomendasi dari mulut ke mulut (word of mouth) yang menguntungkan bagi perusahaan.

Penelitian ini sejalan dengan penelitian Montol (2018) bahwa jenis Kelamin ( $p=0,008)$ mempunyai hubungan dengan kepuasan pelayanan pasien Jamkesmas ${ }^{13}$. Demikian juga dengan penelitian Budiman (2018) tentang hubungan status demografi dengan kepuasan masyarakat tentang pelayanan Jamkesmas menyatakan bahwa tidak terdapat hubungan antara jenis kelamin dengan tingkat kepuasan pasien terhadap pelayanan jamkesmas $(\mathrm{p}=0,007)^{14}$.

Berdasarkan penjelasan tersebut maka penulis berpendapat bahwa jenis kelamin merupakan sebagai pembeda antara perempuan dengan laki-laki. Banyaknya laki-laki menggambarkan bahwa tingkat pelayanan kesehatan banyak dimanfaatkan oleh jenis kelamin laki-laki bila dibandingkan dengan jenis kelamin perempuan yang berarti pula pada kasus penelitian ini lebih banyak laki-laki yang mengalami masalah kesehatan dibandingkan perempuan.

Berkaitan dengan masalah tersebut maka pihak rumah sakit selayaknya dapat memperlakukan pasien dan menjaga privasinya dengan cara membuat sekat pemisah antara pasien satu dengan lainnya, atau jika memungkinkan menempatkan dalam satu ruangan sebagai ruangan perawatan wanita dan menetapkan ruangan lain sebagai tempat rawat inap ruangan laki-laki. Upaya ini sangat penting untuk dapat membangun kepercayaan, kenyamanan dan kepuasan pasien wanita khususnya dan seluruh pasien pada umumnya.

\section{Hubungan Umur dengan Kepuasan Pasien}

Hasil analisis hubungan umur dengankepuasan pasien rawat inap di RSU Gladish Medical Center Pesawaran diperoleh bahwa dari 85 responden yang berumur produktif ada sebanyak $68(80,0 \%)$ yang puas terhadap pelayanan rawat inap rawat di RSU Gladish Medical Center Pesawaran. Sedangkan dari 63 responden yang berumur tidak produktif terdapat $41(65,1 \%)$ yang tidak puas terhadap pelayanan rawat inap rawat di RSU Gladish Medical Center Pesawaran. Hasil analisis chi square diperoleh $p v=0,000$ maka ada hubungan antara umur dengan kepuasan pasien rawat inap di RSU Gladish Medical Center Pesawaran

Hasil penelitian sesuai dengan konsep Pengertian umur menurut para ahli yang dikutip dalam $^{15}$, menjelaskan bahwa umur adalah masa hidup yang dimiliki manusia. Namun, manusia sebaiknya harus selalu menjalankan hidup sehat dan teratur agar dapat terus hidup sehat. Sehingga, manusia dapat menjalankan aktivitas secara normal. Apabila hal tersebut tidak dilakukan, maka manusia akan terserang penyakit. Penyakit merupakan salah satu hal yang dapat memicu kematian dimana hal ini adalah titik akhir umur dan kehidupan Anda.

Temuan-temuan tersebut sesuai dengan pendapat Suprijanto (2008), bahwa ada perbedaan antara anak-anak dan orang dewasa jika ditnjau berdasarkan umur, ciri psikologis dan ciri biologis. Ditinjau dari segi umur, seseorang yang berumur antara 16-18 tahun dapat dikatakan sebagai orang dewasa an yang 
kurang dari 16 tahun dapat dikatakan masih anak-anak. Ditinjau dari ciri-ciri psikologis, seseorang yang dapat mengarahkan diri sendiri, tidak selalu tergantung pada orang lain, mau bertanggung jawab, mandiri, berani mengambil risiko dan mampu mengambil keputusan, orang tersebut dikatakan telah dwasa secara psikologis ${ }^{16}$.

Penelitian ini Tidak sejalan dengan penelitian Montol (2010) yang membuktikan bahwa umur $(0,003)$ memiliki hubungan dengan kepuasan pelayanan pasien Jamkesmas ${ }^{13}$.

Oleh karena itu menurut penulis bahwa, semakin cukup umur, tingkat kematangan dan kekuatan seseorang akan lebih matang dalam berfikir dan bekerja. Dari segi kepercayaan masyarakat, seseorang yang lebih dewasa lebih dipercaya dari orang yang belum tinggi kedewasaannya. Hasil penelitian ini menunjukkan lebih banyak proporsi pasien produktif yang merasa tidak puas. Hal ini disebabkan bahwa semakin bertambah usia maka semakin besar potensi seseorang untuk mengalami masalah kesehatan. bisa jadi keberadaannya saat ini adalah keberadaan yang kesekian kalinya di rawat di rumah sakit dan pasien belajar dari pengalaman sebelumnya.

Jika pasien memiliki pengalaman yang kurang baik terhadap pelayanan rumah sakit tetapi masih menggunakan pelayanan yang sama karena posisi pasien yang tidak ada pilihan lain kecuali harus mendapatkan pelayanan kesehatan di tempat yang menurut pengalaman sebelumnya kurang memuaskan. Hal itu terjadi karena pertimbangan subjektif. Pengalaman dirawat inap sangat mempengaruhi tingkat kepuasan yang diperoleh. Karena faktor pengalaman merupakan penyebab perubahan dalam pengetahuan, sikap dan perilaku. Pengalaman yang menyenangkan selama dirawat di rumah sakit mempunyai efek yang bermakna pada persepsi pasien terhadap mutu. Oleh sebab itu, kewajiban dan tanggung jawab sekarang terletak pada pemberi pelayanan yaitu rumah sakit, dan Pemerintah sebagai penjaminnnya dengan cara terus memperbaiki pelayanan dan menyamaratakan pelayanan tanpa membedakan status dan tingkat sosial.

\section{Hubungan Pendidikan dengan Kepuasan Pasien}

Hasil analisis hubungan pendidikan dengankepuasan pasien rawat inap di RSU Gladish Medical Center Pesawarandiperoleh bahwa dari 80 responden yang sekolah (responden yang memiliki ijazah pendidikan terakhir baik SD, SMP, SMA atau perguruan tinggi) ada sebanyak $73(91,3 \%)$ yang puas terhadap pelayanan rawat inap rawat di RSU Gladish Medical Center Pesawaran. Sedangkan dari 68 responden yang tidak sekolah (responden yang tidak memiliki ijazah pendidikan terakhir baik SD, SMP, SMA atau perguruan tinggi) terdapat $51(26,6 \%)$ yang tidak puas terhadap pelayanan rawat inap rawat di RSU Gladish Medical Center Pesawaran. Hasil analisis chi squarediperoleh $p v=0,000$ maka ada hubungan antara pendidikan dengankepuasan pasien rawat inap di RSU Gladish Medical Center Pesawaran.

Pendidikan adalah pembelajaran pengetahuan keterampilan dan kebiasaan sekelompok orang yang ditransfer dari satu generasi ke generasi berikutnya melalui pengajaran, pelatihan, atau penelitian. Pendidikan sering terjadi di bawah bimbingan orang lain, tetapi juga memungkinkan secara otodidak. Setiap pengalaman yang memiliki efek formatif pada cara orang berpikir, merasa, atau tindakan dapat dianggap pendidikan. Pendidikan umumnya dibagi menjadi tahap seperti prasekolah, sekolah dasar (SD), sekolah menengah (SMP), dan SMA, dan kemudian perguruan tinggi (PT), universitas atau magang ${ }^{17}$.

Hasil penelitian ini tidak sejalan dengan penelitian penelitian sebelumnya yang membuktikan bahwa tidak terdapat hubungan antara pendidikan dengan tingkat kepuasan pasien Jamkesmas $(\mathrm{p}=0,9)$, sementara penelitian Budiman (2018) membuktikan bahwa terdapat hubungan yang signifikan antara pendidikan dengan tingkat kepuasan pasien terhadap pelayanan Jamkesmas $(\mathrm{p}=0,000)^{14}$.

Penulis berpendapat bahwa pendidikan dapat bersifat formal dan tidak formal. Bersifat formal apabila peningkatan kecakapan itu dilakukan dalam lingkungan khusus (misalnya: sekolah) dan tidak formal apabila kecakapan itu diperoleh lewat pengalaman kehidupan atau belajar sendiri dari lingkungan. Namun apabila dihubungkan dengan fenomena lain maka yang digunakan adalah tingkat pendidikan formal sebab yang diperoleh lewat pengalaman kehidupan atau lingkungan susah ditentukan besarannya kecuali dijadikan variabel tersendiri berupa pengalaman.

Ditinjau dari sisi sosial demografis 
peningkatan derajat pendidikan masyarakat semakin meningkat, pada era tahun 90-an lebih banyak dijumpai masyarakat yang pendidikan terakhir SD atau bahkan tidak sekolah, namun perkembangan selanjutnya tingkat pendidikan yang dijumpai paling banyak saat ini adalah SMA atau SLTA. Peningkatan pendidikan ini berarti juga peningkatan kesadaran dan daya kritis terhadap pelayanan kesehatan. Jika proporsi pasien dengan sekolah yang lebih banyak tidak puas, karena pasien memiliki kemampuan untuk menilai pelayanan apa yang seharusnya menjadi haknya dan mengetahuai kewajiban apa yang harus dilakukan oleh pihak rumah sakit kepada pasien. Pada tahap ini maka pasien dengan mudah membandingkan dengan pelayanan di ruangan atau di rumah sakit lain. Berdasarkan penjelasan ini maka muara dari masalah pelayanan dan kepuasan tetap ada pada pihak rumah sakit sebagai pemberi pelayanan kesehatan.

\section{Hubungan Pekerjaan dengan Kepuasan Pasien}

Hasil analisis hubungan pekerjaan dengankepuasan pasien rawat inap di RSU Gladish Medical Center Pesawaran diperoleh bahwa dari 95 responden yang bekerja ada sebanyak $66(69,5 \%)$ yang puas terhadap pelayanan rawat inap rawat di RSU Gladish Medical Center Pesawaran. Sedangkan dari 53 responden yang tidak bekerja terdapat 29 $(54,7 \%)$ yang tidak puas terhadap pelayanan rawat inap rawat di RSU Gladish Medical Center Pesawaran. Hasil analisis chi squarediperoleh $p v=0,007$ maka ada hubungan antara pekerjaan dengan kepuasan pasien rawat inap di RSU Gladish Medical Center Pesawaran.

Penghasilan yang rendah akan berhubungan dengan pemanfaatan pelayanan kesehatan maupun pencegahan. Seseorang kurang memanfaatkan pelayanan kesehatan yang ada mungkin karena tidak mempunyai cukup uang untuk membeli obat atau membayar tranportasi ${ }^{18}$.

Penelitian dini tidak sama dengan hasil penelitian sebelumnya yang membuktikan bahwa tidak ada hubungan antara pekerjaan ibu dengan kunjungan antenatal care pvalue $=0,757^{19}$, Berdasarkan hal tersebut maka peneliti berpendapat bahwa pekerjaan adalah kegiatan yang direncanakan, yaitu suatu kesibukan yang harus dilakukan terutama untuk menunjang kehidupannya dan kehidupan keluarga. Pekerjaan bukanlah sumber kesenangan tetapi lebih diartikan sebagai usaha untuk pencarian nafkah. Pekerjaan memerlukan pemikiran yang khusus dan tidak dapat dijalankan oleh selain manusia. pekerjaan yang dilaksanakan tidak hanya semata-mata karena hal tersebut menyenangkan, melainkan karena kemauan yang sungguh-sungguh untuk mencapai sesuatu hasil yang kemudian berdiri sendiri atau sebagai benda, karya, tenaga dan sebagainya atau sebagai pelayanan terhadap masyarakat.

Pekerjaan seseorang mencerminkan keadaan sosial dari individu atau keluarga di dalam masyarakat. Individu yang berbeda pekerjaan mempunyai kecenderungan yang tidak sama dalam mengerti dan bereaksi terhadap pelayanan kesehatan yang diterima. Banyaknya pasien dengan status tidak bekerja dan tidak puas dengan pelayanan dikarenakan keinginan pasien yang ingin sembuh total dan tidak ingin kembali dirawat karena penyakit yang sama. Kelompok masyarakatyangtidakbekerjacenderungdipenga ruhioleh lingkungan social yang terbatas dan cenderung lebih banyak menuntut atau mengkritik terhadap pelayanan yang diterimanya jika memang tidak merasa puas bagi dirinya.

\section{Hubungan Penggunaan Asuransi dengan Kepuasan Pasien}

Hasil analisis hubungan penggunaan asuransi dengankepuasan pasien rawat inap di RSU Gladish Medical Center Pesawaran diperoleh bahwa dari 98 responden yang menggunakan asuransi ada sebanyak 67 $(68,4 \%)$ yang puas terhadap pelayanan rawat inap rawat di RSU Gladish Medical Center Pesawaran. Sedangkan dari 50 responden yang tidak menggunakan Asuransi terdapat 27 $(54,0 \%)$ yang tidak puas terhadap pelayanan rawat inap rawat di RSU Gladish Medical Center Pesawaran

Tingkat kepuasan pasien responden yang tidak menggunakan Asuransi dikarenakan ketika pasien menjalani rawat inap di RSU Gladish Medical Center Pesawaran di setiap instansi atau unit yang ada, mereka mendapatkan kepuasan, baik itu berupa kecepatan, keramahan petugas dalam memberikan pelayanan. Dokter ramah dan sopan ketika memeriksa pasien dan memperhatikan keluhan pasien, perawat selalu ada pada saat jam dinas dan selalu melakukan 
tindakan secara berhati-hati, untuk setiap pelayanan yang mereka terima selanjutnya responden yang menggunakan asuransi dokter tidak datang sesuai jadwal.

Berdasarkan hal tersebut maka menurut pendapat peneliti bahwa Asuransi kesehatan dapat mempengaruhi seseorang untuk menggunakan fasilitas kesehatan dan dapat menentukan pilihan dimana mereka menentukan tempat untuk berobat. Proporsi pasien yang menggunakan asuransi merasa tidak puas dapat disebabkan karena kondisi psikologis seseorang dengan kemampuan ekonomi yang rendah. Perasaan inferior tersebut membuat pelayanan yang diberikan seolah-olah berbeda dengan pelayanan yang diberikan kepada pasien lain yang penghasilannya tinggi yang tidak menggunakan asuransi.

\section{Hubungan Tangible dengan Kepuasan Pasien}

Hasil analisis hubungan tangible dengankepuasan pasien rawat inap di RSU Gladish Medical Center Pesawaran diperoleh bahwa dari 80 responden yang menyatakan tangible baik ada sebanyak 57 (71,3\%) yang puas terhadap pelayanan rawat inap rawat di RSU Gladish Medical Center Pesawaran. Sedangkan dari 68 responden yang menyatakan tangible buruk terdapat $35(51,5 \%)$ yang tidak puas terhadap pelayanan rawat inap rawat di RSU Gladish Medical Center Pesawaran. Hasil analisis chi squarediperoleh $p v=0,008$ maka ada hubungan antara tangible dengan kepuasan pasien rawat inap di RSU Gladish Medical Center Pesawaran

Hasil penelitian ini sesuai dengan pendapat Lupiyoadi (2013), Berwujud atau tangibles yaitu kemampuan suatu perusahaan dalam menunjukkan eksistensinya kepada pihak eksternal. Penampilan dan kemampuan sarana dan prasarana fisik perubahan yang dapat diandalkan keadaan lingkungan sekitarnya merupakan bukti nyata dari pelayanan yang diberikan oleh pemberi jasa. Hal ini meliputi fasilitas fisik (contoh: gedung, gudang, dll), perlengkapan dan peralatan yang digunakan, serta penampilan pegawainya ${ }^{20}$.

Hasil ini juga sesuai dengan penelitian yang dilakukan Mernawati \& Zainafree (2016) Analisis Faktor-Faktor Yang Berhubungan Dengan Tingkat Kepuasan Pasien Rawat Jalan Di Puskesmas Lamper Tengah Kecamatan Semarang Selatan Kota Semarang. Kesimpulan penelitian ini adalah adanya hubungan antara faktor (Realibility, assurance, tangible, empathy, responsiveness) dengan kepuasan pasien rawat jalan Puskesmas Lamper Tengah, Kota Semarang ${ }^{21}$.

Keberhasilan sebuah organisasi sangat tergantung pada kemampuan manajemen dalam menyerasikan unsur-unsur karyawan dengan sistem, struktur organisasi, teknologi, tugas, budaya organisasi dan lingkungan Bila pasien merasa nyaman dengan layanan di sebuah Rumah Sakit, maka kenyamanan akan mempengaruhi kepuasan pasien, sehingga mendorong pasien untuk datang berobat kembali. Kenyamanan dan kenikmatan dapat menimbulkan seseorang loyal untuk datang berobat kembali guna mendapatkan layanan kesehatan yang sama, oleh karena itu pihak RSU Gladish Medical Center Pesawaran dapat melakukan pembenahan suasana ruang perawatan, kelengkapan peralatan yang mutakhir dan kerapian petugas kesehatan.

Berdasarkan penjelasan diatas maka menurut pendapat peneliti bahwa kualitas pelayanan tangibles yaitu kemampuan suatu perusahaan dalam menunjukkan eksistensinya kepada pelanggan dalam hal ini pasien, untuk dapat merasakan dan menyimpulkan dengan apa yang yang mereka harapkan dalam pelayanan. Berdasarkan hasil diperoleh sebagian besar responden menanggapi kurang baik terhadap pelayanan wujud yang disediakan oleh pihak rumah sakit, dan sebagian responden menyatakan tidak puas terhadap pelayanan wujud yang di sediakan oleh rumah sakit. RSU Gladish Medical Center Pesawaran dalam memberikan bentuk pelayanan kesehatan, dituntut untuk meningkatkan kuantitas dan kualitas peralatan dengan menggunakan peralatan yang modern, perlengkapan yang tersedia lengkap dan tenaga yang menguasai bidang tugasnya sehingga pasien sudah cukup merasa nyaman untuk mendapatkan perawatan kesehatan di RSU Gladish Medical Center. Bentuk-bentuk pemberian kualitas pelayanan sebagai bukti fisik yang diberikan oleh RSU Gladish Medical Center Pesawaran secara operasional tercermin dari ketersediaan alatalat, perlengkapan-perlengkapan yang digunakan oleh dalam pelayanan kesehatan. Terlihat bukti fisik yang ditunjukkan sesuai penerapannya dalam memberikan pelayanan kepada pasien berhubungan dengan kepuasan konsumen atas pelayanan yang diterima. Artinya bukti fisik dalam kualitas pelayanan, 
sangat penting dalam meningkatkan kepuasan konsumen atas pelayanan yang diterima. Selain itu juga perlu disediakan fasilitas pendukung yang terjaga kondisinya sehingga dapat memberikan keamanan, kenyamanan, kepercayaan dan kepuasan pasien.

\section{Hubungan Realibility dengan Kepuasan Pasien}

Hasil analisis hubungan Realibility dengan kepuasan pasien rawat inap di RSU Gladish Medical Center Pesawaran diperoleh bahwa dari 84 responden yang menyatakan Realibility baik ada sebanyak $60(71,4 \%)$ yang puas terhadap pelayanan rawat inap rawat di RSU Gladish Medical Center Pesawaran. Sedangkan dari 64 responden yang menyatakan Realibility buruk terdapat $34(53,1 \%)$ yang tidak puas terhadap pelayanan rawat inap rawat di RSU Gladish Medical Center Pesawaran. Hasil analisis chi square diperoleh $p v=0,008$ maka ada hubungan antara Realibility dengan kepuasan pasien rawat inap di RSU Gladish Medical Center, Pesawaran

Menurut Muninjaya 2011), keandalan (Realibility) merupakan kemampuan untuk memberikan pelayanan kesehatan dengan tepat waktu dan akurat sesuai dengan yang ditawarkan. Untuk meningkatkan Realibility di bidang pelayanan kesehatan, piak manajemen puncak perlu membangun budaya kerja bermutu yaitu budaya tidak ada kesalahan yang diterapkan mulai dari pimpinan pucak sampai ke front line staff (yang langsung berhubungan dengan pasien ${ }^{22}$. Budaya kerja seperti ini perlu diterapkan membentuk kelompok kerja yang kompak dan mendapat pelatihan secara terus menerus sesuai dengan perkembangan teknologi dan ekspektasi pasien.

Pelayanan yang dapat diandalkan mengandung unsur; melakukan apa yang sudah dijanjikan kepada pasien, profesional dalam melayani pasien dan ketepatan dalam memberikan informasi kepada pasien. Jika hal tersebut dapat diberikan kepada pasien, maka kepuasan pasien yang pada akhirnya akan berpengaruh pada tingginya kepuasan pasien.

Berdasarkan dari beberapa indikator Realibility ada beberapa yang menjadi indikator dalam Realibility antara lain prosedur penerimaan pasien yang akurat, pelayanan petugas kesehatan, perawat yang akurat, petugas kesehatan dan perawat dapat dihandalkan dalam menangani masalah, petugas kesehatan perawat dan karyawan administrasi dapat menyampaikan pelayanan yang akan diberikan sejak pertama kali pasien datang dan petugas kesehatan RSU Gladish Medical Center Pesawaran dapat menepati pelayanan sesuai dengan yang di janjikan. Dari beberapa indikator tersebut akan di hubungkan dengan hasil penelitian yang telah dilakukan. Di ketahui bahwa sebagian besar responden berada pada kategori kurang baik. Hal ini sesuai dengan fenomena yang ditemukan oleh peneliti. dimana berdasarkan observasi diawal yang telah peneliti lakukan diketahui bahwa Realibility di RSU Gladish Medical Center Pesawaran kurang baik.

Adapun penyebab dari masalah yang ada berkaitan dengan kehandalan petugas kesehatan adalah masih ada diagnose petugas kesehatan yang kurang akurat, masih ada petugas kesehatan datang tidak tepat waktu dan terburu-buru artinya tidak sesuai dengan yang petugas kesehatan janjikan kepada pasien semenjak pertama kali datang ke rumah sakit oleh karena itu pihak manajemen dan pegawai benar-benar menjalankan system penerimaan pasien sesuai dengan standard operasional prosedur (SOP) RSU Gladish Medical Center.

Berdasarkan hasil penelitian maka peneliti berpendapat kemampuan perusahaan untuk mewujudkan janji dan untuk mengukur kemampuan perusahaan dalam memberikan jasa yang tepat dan dapat di andalkan dapat ditingkatkan. Keandalan (Realibility), yakni kemampuan memberikan pelayanan yang dijanjikan dengan segera, akurat, dan memuaskan. Perwujudan kualitas pelayanan dalam konteks pelayanan kesehatan adalah kemampuan petugas kesehatan memberikan pelayanan yang dijanjikan dengan tepat, akurat dan terpercaya, Karena sebagian besar responden menyatakan kurang baik terhadap keandalan pelayanan kesehatan yang dilakukan petugas kesehatan, dan sebagian besar responden menyatakan tidak puas terhadap keandalan dari pelayanan yang diberikan oleh tenaga kesehatan. Pihak RSU Gladish Medical Center Pesawaran menyadari akan arti dari suatu keunggulan dalam persaingan pelayanan. Disadari pula bahwa saat ini paradigma pelayanan telah mengalami perubahan dari paradigma pelayanan yang mengarah kepada pelayanan yang bersifat ekonomis. Untuk memberikan kepuasan dengan perubahan paradigma tersebut, maka RSU Gladish Medical Center Pesawaran telah mengembangkan bentuk kualitas pelayanan 
kehandalan yang mengarah kepada pelayanan yang mandiri, profesional dan unggul. Bentukbentuk pelayanan tersebut yang berkaitan dengan kualitas kehandalan berupa proses pelayanan yang cepat, sikap pelayanan yang utama dan menanamkan kepercayaan pada setiap pasien. Kehandalan para petugas dalam memberikan pelayanan kesehatan terhadap kepuasan pasien yaitu berupa: (1) proses pelayanan yang diberikan kepada pasien yang cepat, (2) sikap dalam memberikan pelayanan kepada setiap konsumennya dilakukan dengan keramahan dan (3) sikap yang dapat menanamkan kepercayaan kepada setiap konsumen.Kehandalan yang ditunjukkan sesuai dalam memberikan pelayanan kepada pasien dan berpengaruh terhadap kepuasan. Artinya, kehandalan dalam kualitas pelayanan, perlu dipertahankan dan ditingkatkan, sehingga memberikan kepuasan bagi pasien.

\section{Hubungan responsivenes dengan Kepuasan Pasien}

Hasil analisis hubungan Responsivenes dengankepuasan pasien rawat inap di RSU Gladish Medical Center Pesawaran diperoleh bahwa dari 80 responden yang menyatakan Responsivenes baik ada sebanyak $56(70,0 \%)$ yang puas terhadap pelayanan rawat inap rawat di RSU Gladish Medical Center Pesawaran. Sedangkan dari 68 responden yang menyatakan Responsivenes buruk terdapat $34(50,0 \%)$ yang tidak puas terhadap pelayanan rawat inap rawat di RSU Gladish Medical Center Pesawaran. Hasil analisis chi squarediperoleh $p v=0,021$ maka ada hubungan antara Responsivenes dengan kepuasan pasien rawat inap di RSU Gladish Medical Center Pesawaran.

Hal ini sesuai dengan dengan sesuai pendapat Muninjaya 2011), daya tanggap (responsiveness) merupakan kemampuan petugasa kesehatan menolong pelanggan dan kesiapannya melayani sesuia prosedur dan bisa memenuhi harapan pelanggan Berdasarkan dari beberapa indikator responsiveness ada beberapa yang menjadi indikator dalam responsiveness antara lain tindakan cepat oleh petugas kesehatan, perawat, dan administrasi, petugas kesehatan, perawat, dan administrasi memberikan informasi yang jelas kepada pasien yang berhubungan dengan perawat dan petugas kesehatan, perawat dan karyawan administrasi memberikan tanggapan yang cepat dala $\mathrm{m}$ menyelesaikan keluhan pasien ${ }^{22}$.

Bermula dari beberapa indikator tersebut akan di hubungkan dengan hasil penelitian yang telah dilakukan. Diketahui bahwa sebagian besar responden berada pada kategori baik. Hal ini tidak sesuai dengan fenomena yang ditemukan oleh peneliti, dimana berdasarkan obeservasi diawal yang telah peneliti lakukan diketahui bahwa responsiveness di RSU Gladish Medical Center Pesawaran tidak baik. Dan hal ini dimungkinkan, pada saat peneliti melakukan observasi, peneliti hanya melihat dari satu orang petugas saja seperti petugas kesehatan.

Pelayanan yang diberikan petugas (petugas kesehatan) merupakan salah satu penunjang keberhasilan pelayanan kepada pasien yang sedang menjalani pengobatan serta perawatan khususnya pasien rawat inap. Perilaku pelayanan diantaranya ditunjukkan sikap petugas kesehatan dalam melayani pasien. Sikap yang ditunjukkan dengan tingkah laku hendaknya memenuhi norma yang dikehendaki oleh masyarakat terutama oleh penderita dan keluarga pasien.

Dalam memberikan pelayanan seorang petugas kesehatan harus bersikap sopan, sabar, ramah, tidak ragu-ragu, penuh perhatian terhadap penderita, selalu memberikan pertolongan yang di berikan, membina hubungan yang baik dengan perawat yang menangani pasien, menjalin hubungan yang baik dengan pasien dan keluarganya agar timbul kepercayaan penderita kepada petugas kesehatan tersebut. Hal ini tentunya harapan dari setiap pasien dan menjadi tanggung jawab penyedia jasa dalam hal ini petugas yang langsung berhubungan dengan pasien. Bagaimana petugas merespon setiap keluhan dan keinginan pasien dengan cepat dan sesuai dengan standar pelayanan yang telah ditetapkan. Hal ini tentunya akan meningkatkan rasa puas kepada pasien yang pada akhirnya memengaruhi tingkat kepuasan di RSU Gladish Medical Center Pesawaran. Oleh karenannya perlu dipertahankan pelayanannya yang selama ini telah berjalan baik yaitu pelayanan yang cepat tanggap (responsiveness) kepada pasien.

Berdasarkan hasil penelitian maka peneliti berpendapat sebagian besar responden menyatakan bahwa daya tanggap yang dilakukan tenaga kesehatan adalah lama, dan sebagian besar pasien berpendapat bahwa mereka merasa kurang puas terhadap ketanggapan dari pelayanan petugas kesehatan. Berbagai bentuk pelayanan yang diberikan oleh RSU Gladish Medical Center Pesawaran 
tentunya mengharapkan adanya daya tanggap atas kualitas pelayanan yang diberikan sesuai tingkat kepuasan pasien. Sangat wajar bahwa dalam memberikan pelayanan yang menyenangkan, kecakapan dalam pelayanan, menciptakan respon yang positif sebagai respon timbal balik antara pihak RSU Gladish Medical Center Pesawaran sebagai pemberi pelayanan dengan pasien guna saling memberikan feedback yang positif bagi proses pemberian kualitas pelayanan yang utama. Bentuk-bentuk pelayanan yang perlu diberikan sangat ditentukan oleh sikap, profesi dan respon atas keluhan pasien. Daya tanggap yang ditunjukkan kepada nasabah diantaranya adalah: (1) penampilan dan raut wajah, serta keramahan petugas kesehatan dalam memberikan pelayanan kepada pasien, (2) penguasaan, kemahiran dan keterampilan dari petugas kesehatan dalam memberikan pelayanan kepada nasabah dan (3) respon petugas atas keluhan pasien dari pelayanan yang diberikan. Daya tanggap yang ditunjukkan petugas kesehatan di RSU Gladish Medical Center Pesawaran saat ini diupayakan telah sesuai penerapannya dalam memberikan pelayanan kepada pasien dan berhubungan dengan kepuasan pasien atas pelayanan yang diterima. Daya tanggap dalam kualitas pelayanan perlu lebih ditingkatkan lagi dan penting dalam mempengaruhi tingkat kepuasan pasien. Kepuasan pasien atas daya tanggap ini berkaitan erat dengan pemenuhan kebutuhan pasien, bahwa pasien mengharapkan pelayanan yang cepat mendapatkan respons serta penanganan setiap kali pasien membutuhkan.

\section{Hubungan Assurance dengan Kepuasan Pasien}

Hasil analisis hubungan Assurance dengan kepuasan pasien rawat inap di RSU Gladish Medical Center Pesawaran diperoleh bahwa dari 92 responden yang menyatakan Assurance baik ada sebanyak $64(69,6 \%)$ yang puas terhadap pelayanan rawat inap rawat di RSU Gladish Medical Center Pesawaran. Sedangkan dari 56 responden yang menyatakan Assurance buruk terdapat $30(53,6 \%)$ yang tidak puas terhadap pelayanan rawat inap rawat di RSU Gladish Medical Center Pesawaran. Hasil analisis chi squarediperoleh $p v=0,009$ maka ada hubungan antara Assurance dengan kepuasan pasien rawat inap di RSU Gladish Medical Center Pesawaran.

Apabila pelayanan yang di terima atau dirasakan dapat menjamin pasien, maka kualitas jasa pelayanan akan di persepsikan sebagai baik dan memuaskan serta jika jasa yang diterima mampu melampaui harapan pasien, maka kualitas jasa di persepsikan sebagai kualitas jasa yang ideal. Sebaliknya jika jaminan atas kualitas jasa yang diterima lebih rendah dari pada yang diharapkan, maka kualitas pelayanan kesehatan akan dipersepsikan buruk atau tidak memuaskan. Oleh karena itu baik tidaknya kualitas pelayanan tergantung pada kemampuan penyediaan pelayanan dalam memenuhi harapan pasien secara konsisten dengan upaya peningkatan rasa percaya pada pasien, membuat pasien merasa aman, petugas kesehatan bersikap ramah dan terampil.

Berdasarkan hasil penelitian maka peneliti berpendapat terdapat responden menyatakan kurang baik terhadap jaminan pelayanan yang dilakukan oleh petugas kesehatan, dan sebagian besar pasien merasa tidak puas terhadap jaminan pelayanan kesehatan yang dilakukan oleh petugas kesehatan. Dewasa ini RSU Gladish Medical Center Pesawaran telah melakukan pembenahan berbagai aktivitas yang sifatnya dapat menumbuhkan jaminan keyakinan pasien atas pelayanan kesehatan dalam bentuk tindakan medis, pelayanan rawat inap, kepastian ketersediaan sarana dan prasarana, kepastian ketersediaan obat, atau bahkan kesembuhan dari pasien. Jaminan yang dimaksud dalam konteks pelayanan kepada pasien dapat menumbuhkan keyakinan atas pelayanan secara operasional, teknis dan manajerial guna memberikan kepuasan kepada pasien. Bentuk jaminan tersebut berupa sikap yang meyakinkan, motivasi yang ditunjukkan, kesesuaian dalam berbagai pelayanan dan tindakan kepada pasien, pelaksanaan standar operasional keperawatan dan penanganan pasien sakit yang dapat memberikan suatu nilai tersendiri yang dapat diyakini oleh setiap pasien. Oleh karenanya untuk memberikan keyakinan kepada pasien dan memberikan kepuasan maka dimensi assurance ini perlu ditingkatkan dengan cara mendisiplinkan kepada setiap petugas bertindak sesuai fungsi dan tugasnya yang telah diuraikan dalam standar operasional prosedur, melengkapi peralatan pendukung medis yang dapat memberikan keyakinan dan kenyamanan pada pasien dalam menjalani pengobatan di rumah sakit, meningkatkan kompetensi petugas kesehatan melalui pemberian pelatihan secara 
berjenjang sehingga dapat mengimplementasikan pelayanan dengan baik dan prima.

\section{Hubungan Empathy dengan Kepuasan Pasien}

Hasil analisis hubungan Empathy dengan kepuasan pasien rawat inap di RSU Gladish Medical Center Pesawaran diperoleh bahwa dari 102 responden yang menyatakan Empathy baik ada sebanyak $69(67,6 \%)$ yang puas terhadap pelayanan rawat inap rawat di RSU Gladish Medical Center Pesawaran. Sedangkan dari 46 responden yang menyatakan Empathy buruk terdapat $25(54,3 \%)$ yang tidak puas terhadap pelayanan rawat inap rawat di RSU Gladish Medical Center Pesawaran. Hasil analisis chi square diperoleh $p v=0,019$ maka ada hubungan antara Empathy dengan kepuasan pasien rawat inap di RSU Gladish Medical Center Pesawaran

Hal ini sesuai dengan pernyataan Sunyoto, 2012) menerangkan empati meliputi kemudahan dalam melakukan hubungan, komunikasi yang baik, perhatian pribadi, dan memahami kebutuhan para pasien ${ }^{23}$. Penelitian yang dilakukan oleh Sriwiyanti (2006) di RS Harapan Pematang Siantar juga menemukan hasil yang sama dimana perhatian (emphaty) berpengaruh terhadap keputusan pasien untuk menggunakan jasa pelayanan di rumah sakit ${ }^{24}$.

Pada dasarnya setiap pasien ingin diperlakukan secara khusus. Dengan demikian rasa empati dari tenaga medis/paramedis merupakan alat utama untuk memenuhi harapan pasien akan perlakuan istimewa tersebut. Empati artinya berdiri di tempat pasien, maksudnya coba memahami apa yang diinginkan dan dirasakan pasien. Perlu ada kesamaan persepsi antara petugas yang melayani pasien tentang pentingnya membina hubungan personal dengan pasien, hal ini dapat dilakukan misalnya dengan mengadakan pelatihan tentang komunikasi.

Oleh karena itu keluhan-keluhan ataupun permintaan pasien harus didengar dengan seksama, menyesuaikan pelayanan dan mengajukan pertanyaan dengan tepat. Jika hal ini dilakukan maka akan meningkatan rasa empati pasien yang pada akhirnya meningkatkan kepuasan. Jika pasien sudah memiliki rasa memiliki dan mempunyai ikatan emosional yang baik dengan rumah sakit, biasanya dia tidak mau pindah untuk dirawat di rumah sakit lain, meskipun terjadi perubahan harga di rumah sakit tersebut. Mereka sudah merasa nyaman, percaya dan empati pada rumah sakit tersebut dan akan dengan mudahnya mempromosikan rumah sakit kepada keluarga dan orang lain. Hal ini secara tidak langsung mempromosikan rumah sakit dan membawa dampak yang positif bagi RSU Gladish Medical Center Pesawaran Kondisi ini perlu dipertahankan dengan meningkatkan perhatian khusus kepada pasien, sunguhsunguh mengutamakan kepentingan pasien, memahami kebutuhan pasien.

Berdasarkan hasil penelitian maka peneliti berpendapat terdapat responden menyatakan kurang baik terhadap kualitas pelayanan empati yang diberikan tenaga kesehatan pada pasien, dan sebagian besar pasien merasa tidak puas terhadap pelayanan empati yang diberikan oleh petugas kesehatan rumah sakit, oleh karenanya perlu ditingkatkan lagi pelayanan emphaty, karena Empati (emphaty) diwujudkan dengan kemampuan petugas kesehatan memprediksi kebutuhan pasien, kemampuan memenuhi kebutuhan pasien, kemampuan memotivasi pasien, kemampuan dan kesediaan memberikan informasi serta kemampuan menyarankan solusi kepada pasien. Pelayanan RSU Gladish Medical Center Pesawaran hingga saat ini telah memberikan suatu kualitas pelayanan yang mengarah kepada perbaikan nilai empati yang ditawarkan kepada konsumen, sehingga konsumen dapat menilai bahwa kepuasan pelayanan yang diterima betul-betul memuaskan. Secara operasional, pihak RSU Gladish Medical Center Pesawaran hingga saat ini telah mengembangkan suatu empati yang ditujukan kepada pasien dalam bentuk sikap dan karakter yang ditunjukkan berupa proses pelayanan yang cepat, tidak pilih kasih dan memberikan kepercayaan kepada konsumen. Empati yang ditunjukkan cukup sesuai dalam memberikan pelayanan kepada konsumen dan berpengaruh terhadap kepuasan pasien atas pelayanan yang diterima. Atau dengan kata lain, empati dalam dimensi kualitas, perlu lebih ditingkatkan lagi dalam meningkatkan kepuasan pasien atas pelayanan yang diterima.

\section{Analisis Multivariat}

Analisis multivariat pada penelitian ini bertujuan untuk mengetahui faktor yang paling dominan berhubungan dengan kepuasan pasien rawat inap di RSU Gladish Medical Center Pesawaran. Faktor yang berhubungan dengan kepuasan pasien rawat inap tersebut adalah 
jenis kelamin, umur, pendidikan, pekerjaan, penggunaan asuransi, tangible, Realibility, responsivenes, assurance, empathy, faktor yang paling dominan berhubungan dengan kepuasan pasien rawat inap di RSU Gladish Medical Center Pesawaran adalah variable pendidikan $(p=0,000$ dan $\mathrm{OR}=22,3)$.

Dominasi variabel Pendidikan dibandingkan dengan variabel lainnya dikarenakan perolehan nilai $p$ yang paling kecil dan nilai OR paling besar sehingga dapat diinterpretasikan bahwa menunjukkan bahwa responden yang sekolah 22 kali merasa puas dengan pelayanan rawat inap di RSU Gladish Medical Center Pesawaran dibandingkan responden tidak sekolah.

Pendidikan berarti bimbingan yang diberikan seseorang terhadap perkembangan orang lain menuju kearah cita-cita tertentu yang menentukan manusia untuk berbuat dan mengisi kehidupan untuk mencapai keselamatan dan kebahagiaan ${ }^{25}$.

Pendidikan adalah upaya persuasi atau pembelajaran kepada masyarakat agar masyarakat mau melakukan tindakan tindakan untuk memelihara, dan meningkatkan kesehatanya. Perubahan atau tindakan pemeliharaan atau peningkatan kesehatan yang dihasilkan oleh pendidikan kesehatan dan didasarkan kepada pengetahuan dan kesadarannya melalui prosespembelajaran. Sehingga perilaku tersebut diharapkan akan berlangsung lama (long lasting) dan menetap (langgeng), karena didasari oleh kesadaran ${ }^{26}$.

Pendidikan diperlukan untuk mendapatkan informasi, misalnya pad hal-hal yang menunjang kesehatannya sehingga dapat meningkatkan kualitas hidup dari infomasi yang diperolehnya. Pendidikan dapat mempengaruhi seseorang termasuk juga perilakunya dan pada umumnya semakin tinggi pendidikan seseorang akan semakin mudah menerima informasi ${ }^{25}$.

Penulis berpendapat pendidikan merupakan pendidikan juga merupakan salah satu faktor yang mempengaruhi persepsi seseorang. Karena dapat membuat seseorang untuk lebih mudah mengambil keputusan dan bertindak. Berpedoman pada tujuan pendidikan diperkirakan bahwa semakin meningkatnya pendidikan yang dicapai sebagian besar penduduk akan dapat memberikan peluang terhadap daya kritis pasien terhadap pelayanan yang diterimanya. Semakin baik tingkat pendidikan akan membuat pasien semakin mengetahui hak-haknya dan mengetahui kewajiban pihak rumah sakit dalam melayani pasien

Pengalaman yang dirasakan oleh pasien dari pelayanan yang diterimanya merupakan keadaan yang mudah dinilai oleh pasien. Perawat dinilai kurang dapat memberi pertolongan yang sifatnya pribadi seperti membersihkan tubuh dan menyuapi makan, pertolongan untuk duduk, berdiri, dan berjalan, tanggapan perawat juga dinilai masih kurang, dan penjelasan atas tindakan yang dilakukan juga dinilai masih kurang karena pasien membutuhkannya membuat pasien tidak puas. Hal ini dinilai oleh pasien yang memiliki pengetahuan cukup karena pasien tahu bahwa tugas tersebut merupakan salah satu tugas dari petugas kesehatan untuk memenuhi kebutuhan dasar pasien antara lain membersihkan tubuh (memandikan pasien) dan memberi makan pasien, serta membantu pasien melakukan mobilisasi.

Pasien dengan pendidikan yang baik juga mudah menilai komunikasi, yaitu tata cara informasi yang diberikan pihak petugas kesehatan kepada pasien dan keluhan-keluhan dari pasien. Bagaimana keluhan-keluhan dari pasien dengan cepat diterima oleh penyedia jasa terutama perawat dalam memberikan bantuan terhadap keluhan pasien. Pasien membutuhkan penjelasan tentang hal-hal yang akan dilakukannya serta tujuan dari tindakannya sebelumnya, seperti menyuntik, mengukur tensi, dan lain-lain. Pasien tidak hanya harus menuruti dan percaya pada semua tindakan tanpa mengetahui tujuan dari tindakan yang dilakukan atasnya. Padahal, pemberian informasi atau pendidikan kesehatan merupakan salah satu hak pasien dan pasien dengan teingkat pendidikan yang tinggi mengetahui hal itu.

Diharapkan pihak pelayanan di rumah
sakit memberikan
terhadap pengobatan yang akan dilakukan, memberikan resep obat yang tepat kepada pasien, dan memberikan tanggapan atau jawaban atas pertanyaan dari pasien dan keluarga pasien, diharapkan agar petugas kesehatan dapat diberikan pelatihan agar dapat melakukan tugas keperawatan dengan lebih baik, dapat memberikan pertolongan yang sifatnya pribadi kepada pasien, memberikan tanggapan yang baik dan ramah atas keluhan pasien, dan memberikan penjelasan atas tindakan yang dilakukan kepada pasien, 
dan yang terpenting pelayanan kesehatan yang menjadi hak pasien tidak harus dibedakan hanya karena perbedaan kelas, golongan dan status sosial.

\section{KESIMPULAN DAN SARAN}

Faktor dominan yang berhubungan dengan kepuasan pasien rawat inap di RSU Gladish Medical Center Pesawaran adalah adalah pendidikan ( $p$ value $=0,000$; OR:22,3).

Untuk dimensi assurance Perawat agar meningkatkan konsultasi dengan pasien, dengan cara memberikan arahan dan pendidikan kesehatan terhadap pasien, sehingga pasien merasa lebih nyaman. Untuk dimensi Realibility agar dokter meningkatkan kedisiplinan untuk melakukan pemeriksaan terhadap pasien misalnya dengan melakukan kunjungan tepat pada waktunya. Untuk dimensi Tangibles sebaiknya Rumah sakit dapat mempersiapkan ruang rawat inap dengan tempat tidur yang rapi, bersih dan siap pakai oleh pasien. Tingkat pendidikan pasien dapat memudahkan pasien memahami penjelasan yang diberikan pihak Rumah Sakit oleh karenanya pasien perlu diberikan penjelasan tentang jenis penyakit, tindakan yang diberikan, upaya yang perlu dilakukan untuk kesembuhan pasien sampai kepada hal-hal detil kepada pasien. Saran untuk umur pihak Rumah Sakit meningkatkan komitmen untuk, memberikan pelayanan kepada semua pasien tanpa membedakan umur, kelas, golongan dan status sosial dengan memberikan pelatihan pelayanan prima kepada seluruh pegawai rumah sakit dan program lain yang berorientasi kepada peningkatan kalitas pelayanan. Saran untuk penelitian selanjutnya adalah agar riset selanjutnya dapat dilakukan dengan melibatkan variabel lain yang lebih banyak serta subjek dan sasaran yang lebih luas sehingga hasilnya dapat menutupi kelemahan penelitian ini. Selain itu perlu juga dilakukan dengan metode dan analisis data yang lain agar dapat menjadi variasi riset yang bermanfaat bagi dunia pendidikan.

\section{DAFTAR PUSTAKA}

1. Ricketts TC, Goldsmith LJ. Access in health services research: The battle of the frameworks. Nursing Outlook. 2005 Nov 1;53(6):274-80.

2. Handler A, Issel M, Turnock B. A Conceptual Framework to Measure Performance of the
Public Health System. Am J Public Health. 2001 Aug 1;91(8):1235-9.

3. Levesque J-F, Harris MF, Russell G. Patientcentred access to health care: conceptualising access at the interface of health systems and populations. Int J Equity Health. 2013 Mar 11;12(1):18.

4. Sodani PR, Kumar RK, Srivastava J, Sharma L. Measuring Patient Satisfaction: A Case Study to Improve Quality of Care at Public Health Facilities. Indian J Community Med. 2010 Jan;35(1):52-6.

5. Karanja S, Gichuki R, Igunza P, Muhula S, Ofware P, Lesiamon J, et al. Factors influencing deliveries at health facilities in a rural Maasai Community in Magadi subCounty, Kenya. BMC Pregnancy and Childbirth. 2018 Jan 3;18(1):5.

6. Markey K, Tilki M, Taylor G. Strategies to surmount the potential barriers to providing anti-discriminatory care in Irish healthcare settings. Contemporary Nurse. 2012 Feb 1;40(2):269-76.

7. Wiig S, Aase $\mathrm{K}$, von Plessen C, Burnett S, Nunes F, Weggelaar AM, et al. Talking about quality: exploring how 'quality' is conceptualized in European hospitals and healthcare systems. BMC Health Serv Res. 2014 Oct 11;14(1):478.

8. Okuyama A, Wagner C, Bijnen B. Speaking up for patient safety by hospital-based health care professionals: a literature review. BMC Health Services Research. 2014 Feb 8;14(1):61.

9. Husnah RA. Akreditas Sebagai Upaya Peningkatan Mutu Pelayanan Rumah Sakit [Internet]. INA-Rxiv; 2019 [cited 2021 Sep 1]. Available from: https://osf.io/preprints/inarxiv/3sz9f/

10. Andriani A. Hubungan Mutu Pelayanan Kesehatan Dengan Kepuasan Pasien Diruangan Poli Umum Puskesmas Bukittinggi. Journal Endurance. 2017;2(1):45-52.

11. Ningrum DAW. Hubungan Persepsi Mutu Pelayanan Dengan Kepuasan Pasien Rawat Jalan di Puskesmas Bumiratu Kabupaten Pringsewu Tahun 2016. JURNAL DUNIA KESMAS [Internet]. 2019 [cited 2021 Sep 1];8(1). Available from: http://ejurnalmalahayati.ac.id/index.php/duni akesmas/article/view/37-44

12. Woro M, Naili F. Pengaruh Nilai Pelanggan dan Kualitas Layanan Terhadap Loyalitas Pelanggan, Melalui Kepuasan Pelanggan Pada Pelanggan Bus Efisiensi. Jurnal Administrasi Bisnis [Internet]. 2013 Mar 29 [cited 2021 Aug 31];2(1). Available from: https://ejournal.undip.ac.id/index.php/janis/ar ticle/view/5355 
13. Montol SA. Hubungan Antara Status Demografi Dengan Kepuasan Dalam Pelayanan Pasien Jamkesmas Di Wilayah Kerja Puskesmas Ratahan Kabupaten Minahasa Tenggara [Skripsi]. [Manado]: Universitas Sam Ratulangi; 2014.

14. Budiman S, Herlina N. Hubungan status demografi dengan kepuasan masyarakat tentang pelayanan Jamkesmas di wilayah Puskesmas Tanjungsari Kabupaten Bogor Tahun 2010. Jurnal Kesehatan Kartika. 2010;27:1989-2009.

15. Suharjana. Kebiasaan Berperilaku Hidup Sehat Dan Nilai-Nilai Pendidikan Karakter. Jurnal Pendidikan Karakter. 2012;2(2).

16. Suprijanto. Pendidikan Orang Dewasa (Dari Teori Hingga Aplikasi. Jakarta: Bumi Aksara; 2008.

17. Hardiwinoto. lmu Kesehatan Masyaraka. Yogyakarta;

18. Notoatmodjo S. Metodologi Penelitian Kesehatan. Jakarta: Rineka Cipta; 2012.

19. Lumempouw VJR, Kundre R, Bataha Y. Hubungan Faktor Sosial Ekonomi Ibu Hamil dengan Keteraturan Pemeriksaan Antenatal Care (ANC) di Puskesmas Ranotana Weru Kecamatan Wanea Kota Manado. JURNAL KEPERAWATAN [Internet]. 2016 Nov 3 [cited 2021 Sep 1];4(2). Available from: https://ejournal.unsrat.ac.id/index.php/jkp/arti cle/view/14075

20. Lupiyoadi R. Manajemen Pemasaran Jasa. Jakarta: Salemba Empat; 2013.

21. Mernawati D, Zainafree I. Analisis FaktorFaktor Yang Berhubungan Dengan Tingkat Kepuasan Pasien Rawat Jalan Di Puskesmas Lamper Tengah Kecamatan Semarang Selatan Kota Semarang. Public Health Perspective Journal [Internet]. 2016 [cited 2021 Sep 1];1(1). Available from: https://journal.unnes.ac.id/nju/index.php/phpj /article/view/7755

22. Muninjaya GAA. Manajemen Mutu Pelayanan Kesehatan. Jakarta: EGC; 2011.

23. Sunyoto D. Konsep Dasar Riset Pemasaran dan Perilaku Konsumen. Yogyakarta: CAPS; 2012.

24. Sriwiyanti E. Analisis Kualitas Pelayanan Terhadap Keputusan Pasien Memilih Untuk Dirawat Di Rumah Sakit Harapan Pematangsiantar Studi Kasus Di Unit Instalasi Rawat Inap [Tesis]. [Medan]: Universitas Sumatera Utara; 2006.

25. Wawan A, Dewi. Teori dan Pengukuran Pengetahuan, Sikap dan Perilaku Manusia. Yogyakarta: Nuha Medika; 2010.

26. Notoatmodjo S. Promosi Kesehatan. Teori dan Aplikasi. Jakarta: Rineka Cipta; 2005. 